Formatif: Jurnal Ilmiah Pendidikan MIPA

Vol. 8, No. 2, Agustus 2018, pp. 149-158

p-ISSN: 2088-351X

e-ISSN: 2502-5457

DOI: http://dx.doi.org/10.30998/formatif.v8i2.2746

\title{
Physics Module Design of Measurement Subject under Constructivism Approach
}

\section{Pengembangan Modul Pembelajaran Fisika dengan Pendekatan Konstruktivisme pada Pokok Bahasan Pengukuran}

\author{
Sigit Dwi Saputro (*) \\ Universitas Trunojoyo Madura \\ Jalan Raya Telang PO BOX 2 Kamal, Bangkalan \\ Suparmi \\ Universitas Sebelas Maret \\ Cari \\ Universitas Sebelas Maret \\ Aisyah Fidiyah \\ MAN Bangkalan \\ Titin Sandias Budi Ningsih \\ SMA Negeri 4 Bangkalan
}

\section{Received: February 26, 2018 \\ Revised: April 8, 2018 \\ Accepted: August 6, 2018}

\begin{abstract}
This aim of the research is to make valid, practical, and effective constructivism learning. The development of constructivism learning module applies Borg's research procedure theory, basically consisting of: (1) preliminary study and data collection, (2) planning, (3) developing initial product, (4) limited testing, (5) revising product (6) conducting field tests, (7) revising the operational product, (8) conducting operational field tests, (9) revising the final product, and (10) eliminating and implementing the product. This module is for class $\mathrm{X}$ students on the subject of measurement. Students will be able to learn independently by constructivist principles. The results of this study include (1) Creation of constructivism learning module from requirement analysis, module design, expert validation, small-scale module test revision, large-scale module test revision. (2) the feasibility of constructivism learning module that includes physics constructivism learning module on measurement material in the expert test included in the valid category and without revision with percentage level $76 \%$. Student responses on the small-scale test as well as large-scale test get the positive response.
\end{abstract}

Keywords: module, constructivism learning, measurement

(*) Corresponding Author:

sigitd.saputra@trunojoyo.ac.id

How to Cite: Saputro, S. D., Suparmi, Cari, Fidiyah, A., \& Ningsih, T. S. B. (2018). Physics module design of measurement subject under constructivism approach. Formatif: Jurnal Ilmiah Pendidikan MIPA, 8 (2): 149-158. http://dx.doi.org/10.30998/formatif.v8i2.2746

Note: Artikel ini telah dipresentasikan dalam kegiatan Seminar Nasional Pendidikan KALUNI, yang diselenggarakan oleh Keluarga Alumni Univ. Indraprasta PGRI pada tanggal 28 April 2018. 
Formatif: Jurnal Ilmiah Pendidikan MIPA

Vol. 8, No. 2, Agustus 2018, pp. 149-158

p-ISSN: 2088-351X

e-ISSN: 2502-5457

DOI: http://dx.doi.org/10.30998/formatif.v8i2.2746

\section{PENDAHULUAN}

Fisika merupakan pelajaran yang memberikan pengetahuan tentang alam semesta untuk berlatih berpikir dan bernalar, melalui kemampuan penalaran seseorang yang terus dilatih sehingga semakin berkembang, maka orang tersebut akan bertambah daya pikir dan pengetahuannya. Atas dasar inilah Fisika mutlak wajib diajarkan pada setiap siswa. Fenomena tersebut merupakan masalah yang serius dan perlu mendapatkan perhatian penuh dari semua pihak, baik pemerintah, sekolah, masyarakat/ orang tua maupun siswa itu sendiri.

Dalam belajar fisika harus mampu mengembangkan keterampilan, sikap, nilai ilmiah, dan menguasai konsep sains (Kemdiknas, 2003). Penguasaan konsep sains memerlukan sebuah strategi, pendekatan, metode pembelajaran yang dapat meningkatkan kemampuan berfikir siswa. Selain dari penerapan pembelajaran yang tepat harus didukung media pembelajaran yang disusun secara terperinci, salah satu media tersebut adalah modul pembelajaran. Di sinilah peran guru sangat penting sebagai pengembang pembelajaran, agar pembelajaran benar-benar mencapai tujuan yang diharapkan. Leonard \& Chaidir (2018) mengungkapkan keberhasilan dalam proses pembelajaran juga dinilai dari apa yang telah diperoleh siswa dalam pembelajaran, ... oleh karena itu, seorang guru perlu langkah nyata dalam membuat desain pembelajaran yang disusun secara baik dan seimbang.

Modul merupakan bagian dari bahan ajar secara cetak dan suatu perangkat pembelajaran mandiri yang disusun sedemikian rupa berisi tentang suatu materi guna mencapai tujuan tertentu (Depdiknas, 2010). Penyusunan modul menjadi sangat penting disebabkan ada sistematika yang dapat membuat siswa untuk lebih mudah dalam memahami konsep materi, selain hal tersebut modul dapat dipelajari baik didalam ruang kelas maupun pada saat siswa berada di luar kelas misal belajar ditepat-tempat yang dianggap nyaman untuk belajar.

Penyusunan modul dikemukakan oleh Arsyad (2011) yaitu memiliki kriteria tertentu setiap unit informasi dapat tersajikan dengan baik siswa juga diminta memberikan respon yaitu dengan menjawab pertanyaan dari soal yang disajikan dalam media tersebut. Dengan demikian, modul menajadi media pembelajaran efektif dalam pembelajaran. Pentingnya penggunaan modul dalam pembelajaran disampaikan oleh Yunita dkk (2014) yang mengatakan modul juga dapat digunakan sebagai bahan pelengkap pembelajaran bagi peserta didik, serta sebagai bahan latihan mandiri. Hal ini disebabkan peneliti melakukan analisis tugas yaitu mengidentifikasi tugas-tugas siswa dalam kegiatan pembelajaran. Analisis tugas dilakukan dengan penyampaian pesan yang membahas semua inti materi dalam pembelajaran, sehingga siswa dapat mengerjakan tugas yang disediakan modul.

Hasil Penelitian tentang modul juga dikemukakan oleh Lasmiyati dkk (2014) yang menyimpulkan bahwa modul pembelajaran matematika hasil pengembangan telah layak digunakan dalam pembelajaran matematika di sekolah yang terkait dengan meningkatkan pemahaman konsep dan minat belajar matematika siswa. Selain mampu memberikan pemahaman konsep yang nyata modul juga dapat meningkatkan minat belajar dari siswa.

Begitu halnya tingkat pemahaman siswa menggunakan modul dikemukakan oleh Muhafid (2013) yaitu pembelajaran menggunakan modul IPA terpadu menunjukan hasil positif. Hal tersebut terlihat dari jumlah siswa yang tuntas sebanyak 37 siswa dengan ketuntasan belajar siswa secara klasikal 100\% termasuk dalam kriteria "sangat baik" dan rata-rata nilai 90,40. Keberhasilan penggunaan modul IPA te padu dikarenakan siswa dapat memahami modul IPA terpadu yang disajikan.

Modul merupakan salah satu solusi dalam pembelajaran dekemukakan Wenno (2010) modul pembelajaran sains berbasis problem solving method, dan sistem evaluasi 
Formatif: Jurnal Ilmiah Pendidikan MIPA

Vol. 8, No. 2, Agustus 2018, pp. 149-158

p-ISSN: 2088-351X

e-ISSN: 2502-5457

DOI: http://dx.doi.org/10.30998/formatif.v8i2.2746

berdasarkan karakteristik siswa dalam pembelajaran sains dapat dikembangkan lebih lanjut sebagai alternatif pemecahan masalah proses pembelajaran. Modul menjadi salah satu solusi alternative yang dapat memecahkan masalah dalam proses pembelajaran sain hal ini desebabkan modul juga memperhatikan karakteristik siswa pada saat proses pembuatanya.

Modul yang akan diterapkan adalah modul pembelajaran konstruktivis. Konstruktivisme berdasarkan pada premis bahwa kita semua mengonstruksi perspektif kita sendiri terhadap dunia, melalui pengalaman individu dan skema. Konstruktivisme memfokuskan pada persiapan pembelajar untuk mengatasi masalah dalam situasi yang ambigu (Schuman (Smith 2010: 73)).

Sharon et al (2014) mengungkapkan bahwa dalam pembelajaran konstruktivis peserta didik dituntut mampu mempelajari secara mandiri untuk memperoleh pengetahuan. Kemandirian peserta didik menjadi unsur utama dalam belajar secara konstruktivisme, dengan demikian proses belajar menitik beratkan pada aktifitas belajar siswa. Dalam proses belajar siswa merupakan unsure pokok yang menjadi indikator ksesuksesan dalam belajar, jika siswa mampu memiliki kesadaran secara mandiri maka konsep pengetahuan akan lebih mudah untuk dipahami.

Penggunaan pendekatan konstruktivisme melalui metode eksperimen disertai diskusi kelompok ternyata memberikan hasil yang lebih baik, hal ini dikarenakan pada pendekatan konstruktivisme melalui metode eksperimen disertai diskusi kelompok siswa mampu menemukan dan membangun konsep yang ditanamkan guru dan melalui percobaan sendiri dengan berdasarkan konsep yang telah dimilikinya, sehingga pendekatan konstruktivisme sangat mendukung jika dilakukan dengan menggunakan metode eksperimen disertai diskusi kelompok, karena dengan metode eksperimen disertai diskusi kelompok siswa akan selalu dapat melakukan percobaan sendiri dan secara teratur sehingga konsep-konsep yang didapat secara bertahap melalui serangkaian eksperimen akan selalu tetap melekat kuat pada ingatannya (Warsiningsih, 2010).

Begitu halnya Afandi (2009) yang mengungkapkan pembelajaran Fisika dengan pendekatan konstruktivisme melalui metode resitasi secara berkelompok dan individual, keduanya sama-sama mempunyai kelebihan yang mampu membuat siswa untuk aktif dalam belajar. Metode resitasi sesuai dengan pendekatan konstruktivisme karena metode ini sangat menekankan tanggung jawab siswa untuk menambah pengetahuan, khususnya melalui tugas- tugas yang diberikan sebagai bentuk resitasi dalam pembelajaran. Apalagi dengan adanya kebebasan siswa untuk menyelesaikan tugas kapan pun dan di mana pun, siswa tidak hanya dapat mengerjakan tugas di kelas tetapi juga bisa menyelesikan tugas di rumah, laboratorium, perpustakaan atau tempat lainnya. Di akhir pembelajaran Fisika, pelaksanaan pendekatan konstruktivisme melalui metode resitasi menuntut siswa melaporkan tugas yang telah dikerjakan untuk diserahkan kepada guru.

Sependapat dengan penelitian tersebut Widyarini (2011) menemukan bahwa pembelajaran Fisika pada Pokok Bahasan gerak dengan pendekatan konstruktivisme memberikan pengaruh yang signifikan terhadap konsep pemahaman siswa. Hal ini disebabkan penerapan peta konsep siswa tidak hanya sekedar membaca dan menghafal tetapi juga berusaha untuk menemukan hubungan yang ada dalam materi yang sedang dipelajari sehingga mempermudah pemahaman terhadap materi.

Dalam kaitanya pemahaman konsep Susilowati (2012) menyimpulkan bahwa melalui pendekatan kontruktivis akan bisa mendorong keaktifan peserta didik untuk mengkontruksikan pengetahuan berdasarkan pengalamannya dalam belajar melalui berbagai sumber informasi yang diperoleh. Peserta didik dengan motivasi tinggi aktif dalam mengkontruksikan pengalamannya sehingga dia lebih dapat memahami materi daripada peserta didik yang mempunyai sedang atau rendah. 
Formatif: Jurnal Ilmiah Pendidikan MIPA

Vol. 8, No. 2, Agustus 2018, pp. 149-158

p-ISSN: 2088-351X

e-ISSN: 2502-5457

DOI: http://dx.doi.org/10.30998/formatif.v8i2.2746

Penerapan pendekatan konstruktivisme sangat efektif dalam pembelajaran dikemukakan oleh Kishore (2013) pembelajaran dengan penerapan pendekatan konstruktivisme lebih efektif dibandingkan dengan pembelajaran secara tradisional. Guru seharusnya memberikan kesempatan siswa untuk memahami materi secara mandiri melalui sebuah pertanyaan dan memberikan kesempatan bertanya.

Mata pelajaran fisika di tingkat SMA merupakan pengkhususan IPA dan SMK pengukuran merupakan materi dengan konsep abstrak. Materi besaran dan satuan yang diajarkan di tingkat SMA dan SMK juga merupakan pengulangan materi dari tingkat SMP, walaupun didalamnya terdapa dua tambahan pokok bahasan baru, yaitu dimensi dan angka penting. Namun keduanya merupakan pengkhususan sehingga tetap membutuhkan pemahaman konsep dari materi pengukuran.

Berdasarkan pemaparan fakta-fakta tersebut maka perlu dikembangkan modul pembelajaran secara konstruktivisme pada mata pelajaran fisika pada materi pengukuran. Modul tersebut pembelajaran interaktif tersebut akan mampu membantu siswa belajar secara mandiri ditengah keterbatasan jumlah guru. Penelitian yang dilakukan dibatasi pada materi pengukuran.

Berdasarkan rumusan masalah yang telah dipaparkan di atas maka tujuan pengembangan ini adalah untuk mengatasi permasalahan kurangnya jumlah guru fisika dengan menciptakan modul pembelajaran konstruktivis mata pelajaran fisika pada Bab pengukuran.

\section{METODE}

Penelitian ini merupakan penelitian pengembangan dengan model pengembangan yang digunakan adalah model Borg \& Gall. Menurut Borg \& Gall (1998) prosedur penelitian dan pengembangan pada dasarnya meliputi: (1) studi pendahuluan dan pengumpulan data, (2) perencanaan, (3) mengembangkan produk awal, (4) uji coba terbatas, (5) melakukan revisi terhadap produk utama, (6) melakukan uji lapangan, (7) melakukan revisi terhadap produk operasional, (8) melakukan uji lapangan operasional, (9) melakukan revisi produk akhir, dan (10) mendesiminasi dan mengimplementasikan produk. Menurut Ghufron (2007) bahwa dari kesepuluh langkah model Borg \& Gall dapat dikelompokkan menjadi 4 (empat) langkah, yaitu: (a) pendahuluan, (b) pengembangan, (c) uji lapangan, dan (d) diseminasi, akan tetapi pada penelitian ini langkah diseminasi tidak dilaksanakan.

Pada tahap pendahuluan berisi perumusan masalah dan mengumpulkan informasi. Potensi masalah yang terjadi harus diikuti dengan data empirik yang ada. Potensi masalah diperoleh melalui data pokok pendidikan yang menyatakan bahwa dibangkalan masih kekurangan jumlah pengajar salah satunya adalah guru fisika. Pengumpulan informasi adalah informasi berkaitan bahan untuk perencanaan produk tertentu dan diharapkan dapat mengatasi masalah tersebut kajian pustaka, internet dan berbagai sumber informasi lainya.

Pada tahap pengembangan berisi desain produk dan validasi desain. Pada tahap mendesain produk modul pembelajaran Fisika dengan pendekatan konstruktivisme harus dibuat disesauiakan dengan kaidah penerapan konstruktivisme. Validasi desain merupakan proses kegiatan untuk menilai apakah rancangan produk, secara rasional lebih efektif dari sebelumnya. Validasi dalam hal ini merupakan validasi bersifat penilaian berdasarkan pemikiran rasional. Pada penelitian ini desain produk ditetapkan berdasarkan pemikiran rasional. Pada penelitian ini desain produk ditetapkan berdasarkan analisis kebutuhan potensi dan masalah serta refleksi terhadap penelitian sebelumnya. Validasi produk dapat dilakukan dengan cara menghadirkan beberapa pakar atau tebaga ahli yang sudah 
Formatif: Jurnal Ilmiah Pendidikan MIPA

Vol. 8, No. 2, Agustus 2018, pp. 149-158

p-ISSN: 2088-351X

e-ISSN: 2502-5457

DOI: http://dx.doi.org/10.30998/formatif.v8i2.2746

berpengalaman untuk menilai produk yang dirancang. Pakar yang akan menilai materi dan desain dari modul kontruktivisme yaitu Prof. Suparmi, MA., Ph.D. dan Prof. Cari, MA., $\mathrm{Ph} . \mathrm{D}$ adalah pakar fisika dari Universitas Sebelas Maret.

Tahap berikutnya adalah uji Lapangan yang berisi uji skala kecil dan besar. Uji sekala kecil SMA Assaidiyah dan SMA Darut Assaidiyah. Uji sekala besar SMAN 1 Arosbaya. SMKN 1 Arosbaya, MAN 1 Bangkalan, SMK PGRI Bangkalan dan SMAN 1 Kwanyar.

Subjek uji coba produk dalam penelitian pengembngan ini terdiri atas 1) rancangan uji coba. 2) Subjek uji coba. Produk berupa modul pembelajaran konstruktivisme ini diuji tingkat validitasnya. Tingkat validitas modul pembelajaran konstruktivisme diketahui melalui hasil analisis uji coba melalui berarapa tahap, yaitu 1). Ahli materi dan ahli desain. 2) Uji coba perorangan dan 3). Uji coba lapangan.

Instrumen yang digunakan untuk validitas modul dan besar nilai respon siswa menggunakan angket. Angket diberikan kepada validator dan siswa. Validator akan memeriksa tingkat kesesuaian yang meliputi desain modul, dan isi materi modul dan siswa. Angket untuk mengukur validitas uji ahli memodifikasi Mubasiroh (2013). Siswa diberi angket pada saat uji coba skala kecil dan besar. Angket yang diberikan kepada siswa bertujuan untuk mengetahui respon siswa tingkat respon positif atau negatif (Trianto, 2010). Hasil evaluasi pembelajaran akan dianalisis secara deskriptif kualitatif, dan kuantitatif.

Baik angket uji ahli maupun respon siswa akan dianalisis secara kuantitaf untuk mengetahui kategori dari hasil perhitungan. Menurut Ramadhani (2015:80) untuk menentukan skor presentasi yaitu dengan rumus skor maksimal $=$ Jumlah responden $\mathrm{x}$ Jumlah soal $\mathrm{x}$ 5. Presentase $=$ Skor total $/$ Skor maksimal $\mathrm{x} 100 \%$

Tabel 1. Kategori tingkat skor presentase

\begin{tabular}{clc}
\hline No & \multicolumn{1}{c}{ Kategori } & Skor \\
\hline 1 & Sangat Rendah, perlu di revisi & $0 \%-20 \%$ \\
2 & Rendah, perlu di revisi & $21 \%-40 \%$ \\
3 & Cukup, tidak perlu di revisi & $42 \%-60 \%$ \\
4 & Tinggi, tidak perlu di revisi & $61 \%-80 \%$ \\
5 & Sangat Tinggi, tidak perlu di revisi & $81 \%-100 \%$ \\
\hline
\end{tabular}

\section{HASIL DAN PEMBAHASAN}

\section{Hasil}

Pada tahap pengembangan berisi desain produk dan validasi desain. Validasi produk dapat dilakukan dengan cara menghadirkan beberapa pakar atau tebaga ahli yang sudah berpengalaman untuk menilai produk yang dirancang. Adapun hasil validai ahli diringkas dalam tabel 2.

Tabel 2. Rekap Hasil Uji validasi Ahli

\begin{tabular}{|c|c|c|c|c|c|c|c|c|c|c|c|c|}
\hline \multirow[t]{2}{*}{ No } & \multirow[t]{2}{*}{ Responden } & \multicolumn{8}{|c|}{ Skor untuk butir nomor } & & & \multirow[t]{2}{*}{ Total } \\
\hline & & 1 & 2 & 3 & 4 & 5 & 6 & 7 & 8 & 9 & 10 & \\
\hline 1 & Ahli 1 & 5 & 4 & 4 & 4 & 4 & 4 & 4 & 5 & 5 & 5 & 34 \\
\hline 2 & Ahli 2 & 4 & 4 & 4 & 4 & 4 & 3 & 4 & 5 & 5 & 5 & 32 \\
\hline \multicolumn{2}{|c|}{ Jumlah Skor } & 9 & 8 & 8 & 8 & 8 & 7 & 8 & 10 & 10 & 10 & 76 \\
\hline \multicolumn{2}{|c|}{ Jumlah Skor Ideal } & 10 & 10 & 10 & 10 & 10 & 10 & 10 & 10 & 10 & 10 & $\begin{array}{l}100 \\
76 \%\end{array}$ \\
\hline
\end{tabular}


Formatif: Jurnal Ilmiah Pendidikan MIPA

Vol. 8, No. 2, Agustus 2018, pp. 149-158

p-ISSN: 2088-351X

e-ISSN: 2502-5457

DOI: http://dx.doi.org/10.30998/formatif.v8i2.2746

Keterangan butir nomor

1. Organisasi penyajian secara umum

2. Tampilan umum menarik

3. Keterkaitan yang konsisten antara materi bahasan

4. Cakupan materi

5. Kejelasan dan urutan materi

6. Ketepatan materi dengan KI KD

7. Keterkaitan antara masalah dengan konteks kehidupan/kognisi siswa yang termuat dalam buku siswa/modul

8. Penggunaan bahasa sesuai dengan PUEBI

9. Bahasa yang digunakan komunikatif

10. Kesederhanaan struktur kalimat

Berdasarkan uraian pengisian angket berisi 10 indikator pertanyaan di atas maka perhitungan menurut Ramadhani (2015) persesntase dari uji ahli dapat ditentukan yaitu skor hitung dibagi dengan skor maksimal dikali $100 \%$ mendapatkan data $\frac{76}{100} \times 100 \%=$ $76 \%$ adapun simpulan dari hasil uji ahli adalah modul dalam kategiri tinggi dan tidak perlu revisi.

Penilaian validasi modul yang penulis buat, hal yang menjadi titik tekan dari dua uji ahli lebih mengedepankan pada diskriptif masukan dan saran sebagai landasan revisi pembuatan modul selanjutnya adapun catatan-catatan dari kedua dosen meliputi Prof. Suparmi, M.A.Ph.D.yaitu Modul sudah bisa digunakan. Sedangkan Prof. Cari, M.A.Ph.D meliputi 1) Setiap gambar diusahakan sesuai dengan kondisi nyata; 2) Diberi contoh soal uraian dan kunci jawaban cara membangun pengetahuan; 3)Siswa diberi kesempatan untuk mengungkapkan jawaban dalam bentuk uraian.

Tahap berikutnya adalah uji lapangan yang terdiri dari uji skla kecil dan uji skla besar. Uji lapangan merupakan bentuk untuk menggali data informasi yang sesungguhnya terkait mengenai kondisi modul yang selama ini baik uji lapangan skala kecil maupun skala besar. Kedua uji tersebut menggunakan angket responsiswa. Angket deberikan setelah siswa selesa belajar menggunakan modul pembelajan konstruktivisme, adapaun isi angket sesuai dengan Tabel.3.

Tabel 3. Isian angket respon siswa

\begin{tabular}{ll}
\hline No & Pernyataan \\
\hline 1. & Apakah modul Fisika menarik untuk dipelajari \\
2. & Apakah gambar dalam Modul Mudah dipahami \\
3. & Apakah materi dalam Modul Mudah dipahami \\
4. & Apakah istilah dalam Modul mudah untuk dipahami \\
5. & Pakah bahasa dalam mudul mudah untuk dipahami \\
6. & Apakah modul mampu meningkatkan minat belajar \\
7. & Apakah modul mampu meningkatkan hasil belajar \\
8. & Apakah modul mudah dipelajari sebelum proses pembelajaran \\
\hline
\end{tabular}

Adapun hasil uji lapangan skla kecil dilaksanakan di SMA Assaidiyah dan SMA Darut Tauhid dapat diringkas dalam Tabel 4 
Formatif: Jurnal Ilmiah Pendidikan MIPA

Vol. 8, No. 2, Agustus 2018, pp. 149-158

p-ISSN: 2088-351X

e-ISSN: 2502-5457

DOI: http://dx.doi.org/10.30998/formatif.v8i2.2746

Tabel 4. Data angket penilaian modul uji saampel kecil

\begin{tabular}{|c|c|c|c|}
\hline No & Nama Sekolah & Persentase & Kategori Modul \\
\hline 1. & SMA Assaidiyah & $76 \%$ & Tinggi dan tidak perlu revisi. \\
\hline 2. & SMA Darut Tauhid & $77 \%$ & Tinggi dan tidak perlu revisi. \\
\hline
\end{tabular}

Berdasarkan Tabel 4. SMA Assaidiyah memiliki persentase 76 termasuk dalam kategori tinggi dan tidak perlu revisi. Begituhalnya SMA Darut Tauhid memiliki persentase 77 termasuk dalam kategori tinggi dan tidak perlu revisi.

Berdasaran uji sekala kecil dapat disimpulkan modul dapat digunakan tanpa melalui rivisi dan dapat dilanjutkan ke uji skala besar. Uji skala besar merupakan pengembangan modul setelah melalui proses revisi untuk mengetahui tingkat kelayakan modul yang telah dubuat. Adapun untuk menguji hasil modul di lima sekolah meliputi: SMAN 1 Arosbaya, SMKN Arosbaya, SMAN 4 Bangkalan, MAN Bangkalan dan SMK PGRI Bangkalan yang diringkas dalam Tabel 5.

Tabel 5 Data angket penilaian modul uji saampel besar

\begin{tabular}{|c|c|c|c|}
\hline No & Nama Sekolah & Prosentase & Kategori Modul \\
\hline 1. & SMAN 1 Arosbaya & $81 \%$ & Sangat Tinggi dan tidak perlu revisi. \\
\hline 2. & SMKN 1 Arosbaya & $78 \%$ & Tinggi dan tidak perlu revisi. \\
\hline 3. & SMAN 4 Bangkalan & $80 \%$ & Tinggi dan tidak perlu revisi. \\
\hline 4 & MAN Bangkalan & $82 \%$ & Sangat Tinggi dan tidak perlu revisi \\
\hline 5 & SMK PGRI Bangkalan & $80 \%$ & Tinggi dan tidak perlu revisi \\
\hline 6. & SMAN 1 Kwanyar & $81,25 \%$ & Sangat Tinggi dan tidak perlu revisi \\
\hline
\end{tabular}

Berdasarkan tabel 5, SMAN 1 Arosbaya memiliki persentase 81 termasuk dalam kategori sangat tinggi dan tidak perlu revisi. SMKN 1 Arosbaya memiliki persentase 78 termasuk dalam kategori tinggi dan tidak perlu revisi. SMKN 1 Arosbaya memiliki persentase 80 termasuk dalam kategori tinggi dan tidak perlu revisi. MAN Bangkalan memiliki persentase 82 termasuk dalam kategori sangat tinggi dan tidak perlu revisi. SMK PGRI Bangkalan memiliki persentase 80 termasuk dalam kategori tinggi dan tidak perlu revisi. Dan SMAN 1 Kwanyar memiliki persentase 81,25 termasuk dalam kategori sangat tinggi dan tidak perlu revisi.

\section{Pembahasan}

Modul pembelajaran konstruktivisme fisika pada materi pengukuran dikembangkan dalam bentuk teks yang membangun pengetahuan siswa dan terdapat latihan soal. Berdasarkan beberapa uraian di atas dapat diketahui bahwa modul pembelajaran konstruktivisme fisika pada materi pengukuran yang dikembangkan berkategori valid dengan kategori tinggi dengan nilai prosentase $76 \%$. Hal ini sesuai dengan teori yang ada, bahwa suatu produk hasil pengembangan dikatakan berkategori valid tinggi apabila berada pada rentang 61\%-80\% (Ramadhani, 2015).

Respon siswa terhadap modul pembelajaran konstruktivisme fisika pada materi pengukuran untuk uji skala kecil di SMA Assaidiyah memiliki persentase 76 termasuk 
Formatif: Jurnal Ilmiah Pendidikan MIPA

Vol. 8, No. 2, Agustus 2018, pp. 149-158

p-ISSN: 2088-351X

e-ISSN: 2502-5457

DOI: http://dx.doi.org/10.30998/formatif.v8i2.2746

dalam kategori tinggi dan tidak perlu revisi. Begitu halnya SMA Darut Tauhid memiliki persentase 77. Hal ini sesuai dengan teori yang ada, bahwa suatu produk hasil pengembangan dikatakan berkategori valid tinggi apabila berada pada rentang 61\%-80\% (Ramadhani, 2015). Adapun untuk uji skala besar di SMAN 1 Arosbaya memiliki persentase 81 termasuk dalam kategori sangat tinggi dan tidak perlu revisi. SMKN 1 Arosbaya memiliki persentase 78 termasuk dalam kategori tinggi dan tidak perlu revisi. SMKN 1 Arosbaya memiliki persentase 80 termasuk dalam kategori tinggi dan tidak perlu revisi. MAN Bangkalan memiliki persentase 82 termasuk dalam kategori sangat tinggi dan tidak perlu revisi. SMK PGRI Bangkalan memiliki persentase 80 termasuk dalam kategori tinggi dan tidak perlu revisi. Dan SMAN 1 Kwanyar memiliki persentase 81,25 termasuk dalam kategori sangat tinggi dan tidak perlu revisi. Hal ini sesuai dengan teori yang ada, bahwa suatu produk hasil pengembangan dikatakan berkategori valid tinggi apabila berada pada rentang 61\%-80\% (Ramadhani, 2015). Berdasarkan teori yang ada siswa merespon positif jika besarnya percentage of agreement $\geq 50 \%$ (Trianto, 2010), maka dapat dikatakan modul pembelajaran konstruktivisme fisika pada materi pengukuran mendapat respon positif.

\section{PENUTUP}

Berdasarkan hasil penilitian dan pembahasannya yang telah diuraikan sebelumnya dapat disimpulkan sebagai berikut.

1. Modul pembelajaran konstruktivisme fisika pada materi pengukuran dikembangkan dalam bentuk teks yang membangun pengetahuan siswa dan terdapat latihan soal.

2. Modul pembelajaran konstruktivisme fisika pada materi pengukuran dalam uji ahli termasuk dalam kategori valid dengan tingkat prosentase $76 \%$

3. Respon siswa pada uji skala kecil maupun uji skala besar mendapat respon positif termasuk dalam kategori sangat tinggi dan tanpa revisi dan tinggi tanpa revisi

\section{DAFTAR PUSTAKA}

Afandi, A. N. (2009). Pengaruh Penggunaan Pendekatan Konstruktivisme Pada Pembelajaran Fisika Pokok Bahasan Kalor Ditinjau dari Motivasi Belajar Fisika SMP. Universitas Sebelas Maret.

Arsyad, Azhar. (2011). Media Pembelajaran. Jakarta: Rajawali Press.

Kemendiknas. Undang-Undang Standar Pendidikan Nasional No. 20 Tahun 2003. Jakarta: Kemdiknas PAIKEM (CTL, Pembelajaran Terpadu, Pembelajaran Tematik). Materi Penguatan Pengawas Sekolah.

Kishore, V. (2013). Impact of constructivist learning approach on academic achievement. Management Education \& Research Institute, VII (2), 69-74.

Leonard \& Chaidir, M. (2018). The development of learning design on down syndrome children's number recognition. Formatif: Jurnal Ilmiah Pendidikan MIPA, 8 (1): 17-30. http://dx.doi.org/10.30998/formatif.v8i1.2285

Lismiyati, Harta, Idris (2014). Pengembangan modul pembelajaran untuk meningkatkan pemahaman konsep dan minat siswa SMP. Jurnal Pendidikan Matematika, 9 (2), $161-174$.

Muhafid, E. A. (2013). Pengembangan Modul IPA Terpadu Berpendekatan Keterampilan Proses pada Tema Bunyi di SMP Kelas VIII. Skripsi: Universitas Negeri Semarang. Tidak Dipublikasikan. 
Formatif: Jurnal Ilmiah Pendidikan MIPA

Vol. 8, No. 2, Agustus 2018, pp. 149-158

p-ISSN: 2088-351X

e-ISSN: 2502-5457

DOI: http://dx.doi.org/10.30998/formatif.v8i2.2746

Sharon et al. (2014). Instructional Technology and Media For Learning- Teknologi Pembelajaran dan Media untuk Belajar. Jakarta: Prenadamedia Group.

Smith, Mark K. (2010). Teori Pembelajaran dan Pengajaran. Yogyakarta. Mirza Media Pustaka.

Susilowati, E. (2012). Efektivitas Pembelajaran Open-Ended dan Konstruktivisme Terhadap Prestasi Belajar Matematika Pada Pokok Bahasan Fungsi Turunan ditinjau dari Motivasi Belajar Siswa SMA kelas XI IPS Kabupaten Boyo Lali. Universitas Sebelas Maret.

Warsiningsih. (2010). SMP, Pembelajaran Fisika dengan Pendekatan Konstruktivisme melalui Metode Eksperimen dan Demonstrasi ditinjau Dari Sikap Belajar Siswa pada Sub Pokok Bahasan Pemantulan Cahaya untuk Siswa SMP. Universitas Sebelas Maret.

Widyarini, T. (2011). Pembelajaran Fisika dengan Pendekata Konstruktivisme melalui Metode Demonstrasi dengan menggunakan Peta Konsep dan Flip Chart ditinjau dari Motivasi Belajar Siswa terhadap Kemampuan Kognitif Siswa SMP. Universitas Sebelas Maret.

Winno, I. H. (2010). Pengembangan model modul IPA berbasis problem solving method berdasarkan karakteristik siswa dalam pembelajaran di SMP/MTs. Cakrawala Pendidikan, XXIX (2).

Yunita, Ike Evi, Hakim, Luqman. (2014). Pengembangan modul berbasis pembelajaran kontekstual bermuatan karakter pada materi jurnal khusus. Jurnal Pendidikan Akuntansi (JPAK), 2 (2). 
Formatif: Jurnal Ilmiah Pendidikan MIPA

Vol. 8, No. 2, Agustus 2018, pp. 149-158

p-ISSN: 2088-351X

e-ISSN: 2502-5457

DOI: http://dx.doi.org/10.30998/formatif.v8i2.2746 